\title{
ひずみ検出に光ファイバーグレーティングを用いたボルト軸カセンサの研究
}

\author{
岩田 弘 $^{* 1}$, 柏 美奈子 ${ }^{* 2}$, 水谷 康男 ${ }^{* 2}$
}

\section{Axial force sensor for screw bolt using optical fiber grating for detection of strain}

\author{
Hiromu IWATA $^{* 1}$, Minako KASHIWA ${ }^{* 2}$ and Yasuo MIZUTANI*2 \\ ${ }^{* 1}$ Department of Mechanical Engineering, National Institute of Technology, Kagawa College \\ 355 Chokushi-cho, Takamatsu-shi, Kagawa 761-8058, Japan \\ ${ }^{* 2}$ SHINKO Electric Wire Co., Ltd \\ 1298-12 Shido, Sanuki-shi, Kagawa 769-2101, Japan
}

Received 4 June 2015

\begin{abstract}
In this study, an axial force sensor was developed and evaluated for a screw bolt using optical fiber grating (FBG: fiber Bragg grating). This sensor has high tolerance to electromagnetic noise. Furthermore, it has a characteristic long-distance signal transmission ability because it was made using optical fiber. This washer type sensor forms a circular projection because the stress distribution in the sensor is obtained only proportional to the axial force of the screw bolt. The axial force sensor was experimentally developed for an M10 screw bolt. According to test results, the reflection wavelength shift was proportional to the axial force, implying that this sensor has excellent characteristics.
\end{abstract}

Key words : Axial force sensor, Optical fiber, Fiber grating, FBG, Screw bolt

\section{1. 緒言}

ねじは最も重要な機械要素の一つである. その起源は 15 世紀のルネッサンス期にも遡るとされ，この千年で最 高の発明とも言われる(Rybczynski, 2003). 現代のあらゆる構造物はねじなくして語れないほどである.

しかしながら，ねじの緩みは古くから知られた重要問題であり，近年でも大小含め多くの事故の原因とされて いる．この対策にはダブルナット締結法をはじめとする数多くの提案や製品があり，その信頼性が向上している ようではあるが，ねじの原理上から非常に解決困難な課題とも考えられる。このため，ねじの緩みメカニズムの 解明には多くの研究(山本，賀勢，1977)がおこなわれており，また社会的な関心も高い。さらにボルト緩夕監視 モニタシステムについても各種の方式のセンサが用いられ，多くの製品が提案されている.

本報では，ねじの緩み監視や締結力管理等のために使用するボルト軸力センサについて，センサ内のひずみ検 出に光ファイバー素子を用いた新しい方式のボルト軸力センサを提案する.

この軸力センサは，これまでのセンサのほとんどが電気式であるのに対して，光ファイバー素子を用いている ため新たなメリットが得られる。これは第一に，光ファイバーでは電気信号を用いていないため，電磁ノイズに 対する耐性があり，その影響を受けない点である。エンジン点火時におけるスパーク電流や高圧電線付近におけ る電磁波は電気式計測器にとってはノイズ対策に苦慮する場面である。一方，光ファイバーはこの影響を全く受 けないため，安定して計測が可能である．第二のメリットは，信号の長距離伝送が容易なことである．電気電子 計測の場合は必ず電源が必要となることや，インピーダンスが原因の伝送損失を補うための増幅器の設置も場合 によって必要となる. これに対して光ファイバーは光損失が $0.2 \sim 0.3 \mathrm{~dB} / \mathrm{km} （ 30 \sim 50 \mathrm{~km}$ で信号強度が $1 / 10$ に低 下）と非常に低損失で長距離信号伝送が可能であり，1 km を超える長距離の信号伝送も容易である. 第三のメリ

\footnotetext{
No.15-00308 [DOI: 10.1299/transjsme.15-00308], J-STAGE Advance Publication date : 20 August, 2015

*1 正員，香川高等専門学校（一761-8058 香川県高松市勅使町 355)

*2 伸興電線 (株) (†769-2101 香川県さぬき市志度 1298-12)

E-mail of corresponding author: iwata@t.kagawa-nct.ac.jp
} 
ットは，複数の信号を異なる光波長に割当てることによって相互干渉することなく同時に信号を伝送することが 可能となるため, 複数の光ファイバーセンサを 1 本の光ファイバーに配線することが可能であり, 結果として設 置が容易になることである.

この光ファイバーセンサにも各種の方式があるが，ここでは後述するファイバー・ブラッグ・グレーティング （FBG）素子を用いた．これを用いたのは，光ファイバーFBG 素子が，通常の光ファイバーを用いた後方ブルリ アン散乱を計測する方式などの他の方式に比べて，充分な強度の光信号が得られ，しかも高い測定精度を得やす いという特徵を有していることに理由がある.

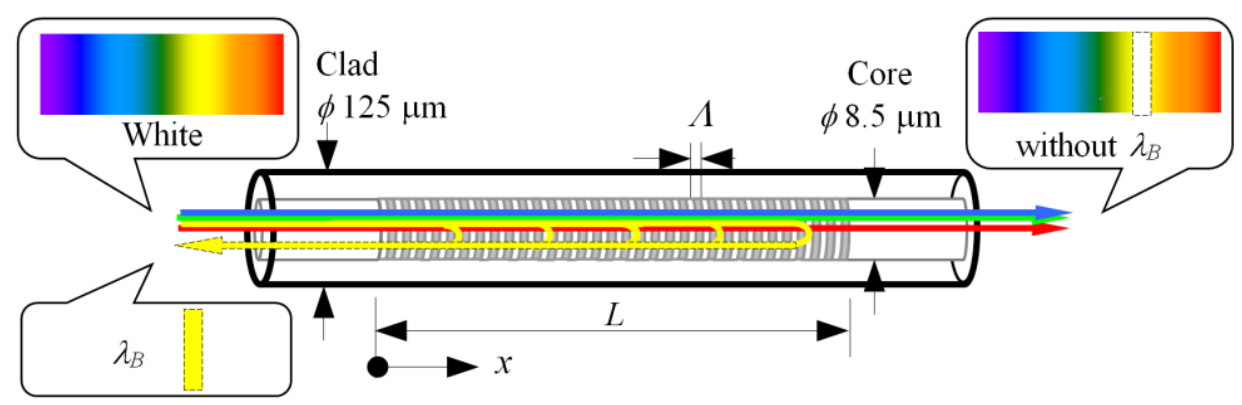

Fig.1 Optical fiber and FBG(Fiber Bragg Grating) device.

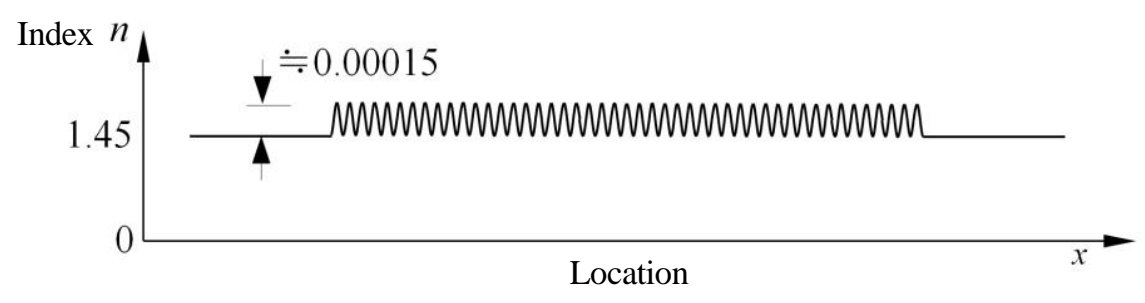

Fig.2 Schematic diagram of index modulation on optical fiber core at FBG device.

\section{2. 光ファイパーFBG 素子}

光ファイバーは DWDM（Dense Wavelength Division Multiplexing, 高密度波長分割多重方式）に代表される高速 情報通信を支える素子として開発されたものである.ここで使用する光ファイバーは，図 1 に示したように，直 径 $125 \mu \mathrm{m}$ の繊維状石英ガラスであり，この軸芯部にある直径 $8.5 \mu \mathrm{m}$ のコア部とその周りのクラッド部から構成 されているシングルモード光ファイバーである.

この光ファイバーに各種の加工を施して光機能素子としての特性を付与することが可能であり，ここでは図 1 に示したような, 光ファイバーFBG（Fiber Bragg Grating）素子を用いた. この光ファイバーFBG 素子は光ファイ バーのコア部にエキシマレーザーなどを用いて高エネルギー加工を行い, 図 2 に示したように, コア部の屈折率 の高低を光軸方向に周期的に分布させた摂動部を設けたものである.一般に光伝搬媒質に屈折率の変化があると, そこで反射が生じる. 光ファイバーFBG 素子の場合, 屈折率摂動の屈折率振幅 $\Delta n$ は通常約 0.00015 と非常に小 さいためこれによる反射はわずかであるが，摂動回数が大きいためこれらの反射光が結合して大きな反射を生じ る. ただし, 反射光が結合するのは摂動周期で光波の位相が同期した場合のみであるため, 捸動周期に依存した 特定の波長でのみ反射が生じることとなる.

この屈折率摂動周期を $\Lambda$ とすると，光ファイバーFBG 素子からの反射波長=Bragg 波長 $\lambda_{B}$ との間には,

$$
\lambda_{B}=2 n \Lambda
$$


の関係がある．このことから，反射波長 $\lambda_{B}$ は摂動周期 $\Lambda$ に比例することになる.

いま，光ファイバーの軸方向に何らかの力が作用したとすると，光ファイバーは石英ガラスと等しい弾性特性 に従って伸縮する．このとき，コア部に形成された屈折率摂動周期も軸方向に伸縮することとなる．屈折率摂動

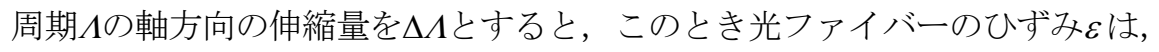

$$
\varepsilon=\frac{\Delta}{\Lambda}
$$

の関係になるので, 式(1)および式(2)を考慮して整理すると, 光ファイバーFBG 素子の反射波長の変化 $\Delta \lambda_{B}$ は,

$$
\Delta \lambda_{B}=2 n \Lambda \varepsilon
$$

\section{として得られる.}

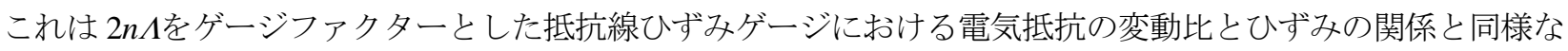
式である. したがって, 反射波長 $\lambda_{B}$ の変化を何らかの方法で計測することによって, 光ファイバーFBG 素子のひ ずみを推定することが可能となる.

なお, 実際の光ファイバーにおける各值は, 本研究において使用したシングルモード光ファイバーSMF-28e

(Corning Co. Ltd.) においては, 屈折率 $n=1.45$ であり, また, 光ファイバーFBG 素子の反射波長 $\lambda_{B}=1550 \mathrm{~nm}$ と したとき，摂動周期 $\Lambda$ は約 $0.5 \mu \mathrm{m}$ である.

\section{3. 軸カセンサと有限要素法を用いた解析}

\section{$3 \cdot 1$ ボルト軸カセンサの基本構造}

ボルト軸力の計測には，超音波を利用してボルトの伸びを計測する方法や圧電素子を用いて力を直接計測する 方法，ひずみゲージを用いてボルトのひずみを計測する方法などがあるが，前章における光つァイバーFBG 素子 のひずみ応答特性から，抵抗線ひずみゲージと同様な構造を用いることが好都合である．ここでは，計測の汎用 性を考慮して, ボルトやナットとは独立したワッシャ型のセンサとし, 光ファイバーFBG 素子を埋め込むために 軸方向厚さを大きくした構造とする.このときワッシャ型センサ内の最大主応力は, ボルト頭部座面半径付近で, ボルト軸方向＝ワッシャ軸方向に平行な向きになるものと考えられる. したがって，ボルト軸力に対して最大の ひずみ感度を得るためには, 最大主応力の方向に光ファイバーFBG 素子を設置することが望ましい. しかしなが ら, ボルト頭部座面の半径で軸方向にグレーティング長 $4.0 \mathrm{~mm}$ の光ファイバーFBG 素子を設置したとき, ボル 卜頭部との干渉を回避して光ファイバーを引き出す必要がある. 光ファイバーFBG 素子は脆性材料である石英ガ ラスでできているため非常に折れやすく曲げ変形強度が極端に低いため, 小さな曲率半径で曲げて引き出すこと が困難である，このような制約のある光ファイバー引き出し線部を考慮して構造設計を試みると, ワッシャ型セ ンサの厚さが $20 \mathrm{~mm}$ 以上となる. このように軸力センサの直径に比べて厚さが大きくなると設置姿勢が不安定に なり取り扱いが難しくなるため，できる限り厚さを小さくすることが望ましいものと考えられる.

このような光ファイバー独特の制約を考慮ながら検討した結果, ボルト軸方向から半径方向に 20 度だけ傾けた 軸（以下， $\mathrm{S}$ 軸という）上に光ファイバーFBG 素子を埋め込んで設置することとした. この光ファイバーFBG 素 子の傾斜によって，軸力に対する光ファイバーFBG 素子のひずみ感度が約 $6 \%$ 低下することが見込まれるが，セ ンサの厚さを約 $10 \mathrm{~mm}$ に抑えることが可能になり, 設置姿勢の安定性と実用性の向上をはかることができた.

次に, ねじ締結時の座面圧分布については, 締付力やこれに伴う弾性変形等によって変化することが知られて いる(賀勢, 1985). また, 通常市販され使用されているねじ座面をよく観察すると, 必ずしも均質で平滑な仕上 げが施されているとは言い難い場合があることがわかった。このためワッシャ型センサとボルトやナットの座面 
の接触領域の圧力分布が不安定になり，これが原因で軸力センサ内部の光ファイバーFBG 素子設置部位の局所 的な応力やひずみがばらつくことが考えられる．これは軸力センサとして信頼性低下の原因である.

そこで，このセンサ特性とボルト座面接触半径によるセンサ特性への影響を検証するため，軸力が作用する荷 重印加点の半径とワッシャ型センサのボルト軸力によって生じるボルト軸から 20 度傾斜した $\mathrm{S}$ 軸上の応力分布 との関係を, 有限要素法を用いた解析によって求めた. この計算では M10 ボルト用軸力センサを想定して, ワッ シャ型センサの内径 $11 \mathrm{~mm}$, 外径 $31 \mathrm{~mm}$, 厚さ $10 \mathrm{~mm}$ とし, 材質はステンレス鋼で縦弹性係数 $E=193 \mathrm{GPa}$. ポ アソン比 $v=0.3$ とした. 有限要素法を用いた解析は軸対称モデル解析とし，センサの半径方向断面において 2 次 元軸対称解析を行った．解析ツールには汎用プログラムである ANSYS(ver.14)を用いた.

本解析時の境界条件は, センサ下面の半径 $r=6.1 \sim 8.9 \mathrm{~mm}$ の領域を軸方向に固定し, 上面側に単位荷重 $1 \mathrm{~N}$ を 軸方向圧縮側に集中荷重を印加した。この荷重印加は，ボルト座面によって生じるワッシャ型センサ上面の圧力 分布重心の半径方向のばらつきを想定しており, 半径 $r=6.1,7.5,8.9 \mathrm{~mm}$ の 3 種類の円周への荷重印加について 解析を行った. このときの単位軸荷重あたりの $\mathrm{S}$ 軸方向応力分布の計算結果を, 図 3 に示した. この結果に よると, $\mathrm{S}$ 軸上 $-2.0 \sim 2.0 \mathrm{~mm}$ の領域における応力の平均值は $3.8 \mathrm{kPa} / \mathrm{N}$ であった. 図のように, 荷重印加 点半径の変化による $\mathrm{S}$ 軸上の応力分布は比較的大きく変動するが, この応力変動幅は, $\mathrm{S}$ 軸上の $s=-2.0,0$, $2.0 \mathrm{~mm}$ の位置においてそれぞれ，1.18，0.29，2.17 kPa/N であった. 平均応力 $3.8 \mathrm{kPa} / \mathrm{N}$ と比較すると，この 変動值は相対的にかなり大きい. この計算結果からボルト座面圧力分布のばらつきは FBG 素子にかかる応 力分布に大きな変化をもたらす可能性があることがわかった. またこの計算結果のように, 荷重印加点半径 によって応力変動の傾向が大幅に異なり, 応力の分布形状が変化することも光ファイバーFBG 素子を使用 する上で問題がある.これは，抵抗線ひずみゲージのようにゲージ長全体での平均のひずみを抵抗值の変化 として出力する場合にはあまり問題にはならないものと考えられるが，一方，光ファイバーFBG 素子の場 合はグレーティング長における不均一なひずみ分布がグレーティング内部における局所的な反射波長の不 揃いをもたらし，これが光ファイバーFBG 素子の反射光のスペクトル分布形状の歪みとなって現れる.こ のとき, 軸力とスペクトルとの関係を求めることが困難になる場合があるためである.したがって測定精度 と安定性の良いセンサとするには, 座面の荷重印加点半径すなわちボルト座面接触半径を一定にして, 軸力 センサ内の応力分布を安定させる必要がある.

このためワッシャ型軸力センサの試作においては，図４に示したように，センサの上下面に円周状の突起部を 設けて, ボルト座面との接触をこの突起部半径に固定し, 軸力の印加半径を安定させた．このことによって, 軸 カセンサ内部の応力分布の安定化を図ることが可能になった.

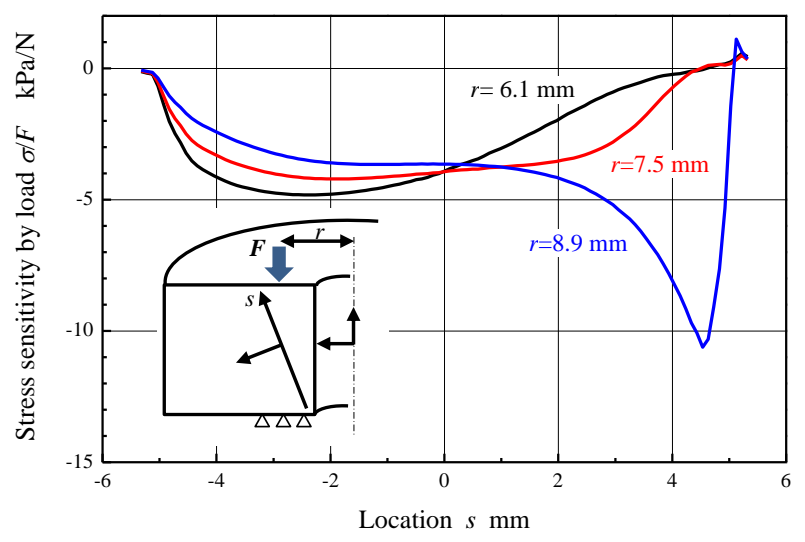

Fig.3 Analytical result of stress sensitivity distribution on s-axis. The stress of washer type sensor was analyzed. This plot shows the stress distribution on $\mathrm{S}$-axis caused about with the axial force with radius $r$. It became clear that this stress distribution changes with radius $r$ a lot. 


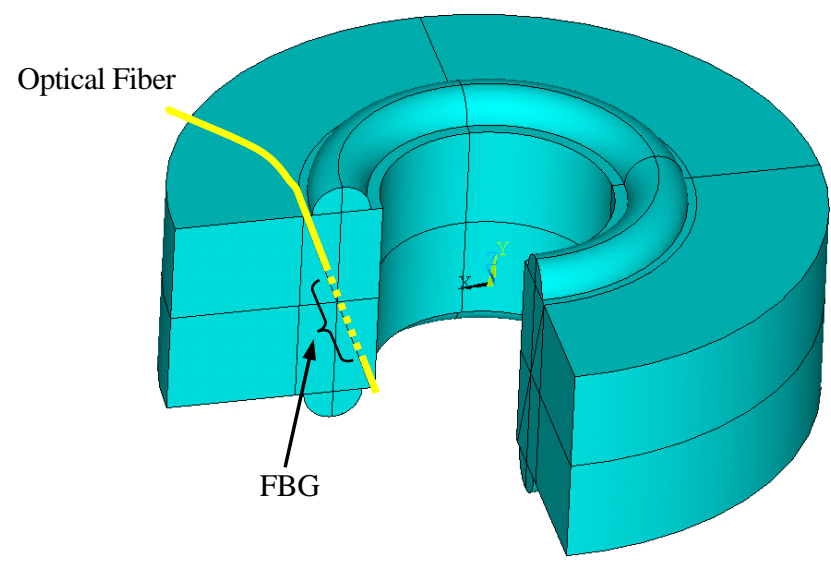

Fig.4 Axial Force Sensor (3/4 cut-model). As shown in this figure, optical fiber FBG device tilted over and was embedded.

\section{$3 \cdot 2$ 軸カセンサの解析緒元}

ボルト座面の接触半径の安定化のために円周状突起部を設けた軸力センサは，前節の解析モデルと同じく $\mathrm{M} 10$ のボルトを想定して, 内径 $11 \mathrm{~mm}$, 外径 $31 \mathrm{~mm}$, 厚さ $10 \mathrm{~mm}$ とした. また, 円周状突起部は直径 $15 \mathrm{~mm}$ の位置 に半径 $1.4 \mathrm{~mm}$ の半円状断面で上下面に設けている. センサの材質はステンレス鋼を想定し，縦弾性係数 $E=193$ GPa. ポアソン比 $v=0.3$ とした.

有限要素法を用いた解析は軸対称モデル解析とし，半径方向断面において 2 次元解析を行った．また解析時の 境界条件は軸力を受ける突起部のうち, 下面突起部の最下端を軸方向に固定し，上面突起部の最上端に単位荷重 $1 \mathrm{~N}$ を軸方向圧縮側に印加して計算した。 このほかトルク荷重による影響を計算するために，この上面突起部に $1.0 \mathrm{Nm}$ の単位モーメント荷重を印加して計算を行った.

この軸力解析モデルを図 5 に示した.

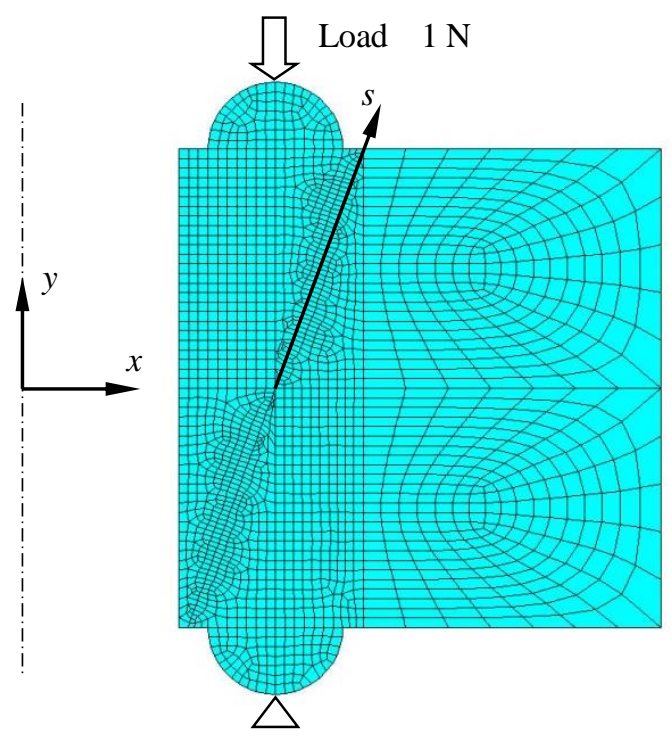

Fig.5 Finite element model and boundary conditions for axial force sensor using ANSYS. 


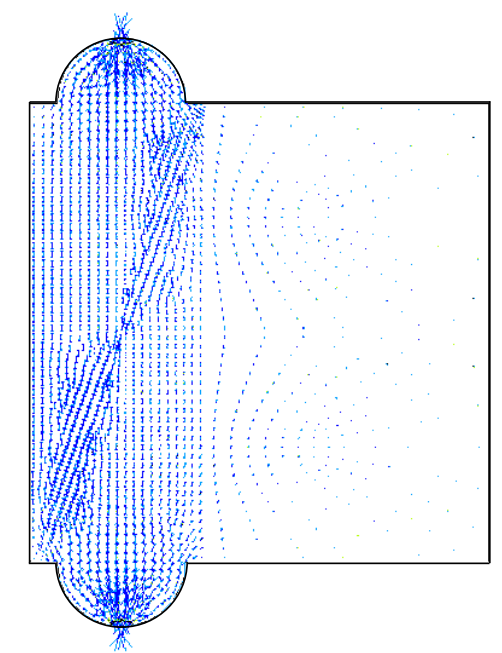

Fig.6 Analytical result of FEM analysis: Vector plot of stress distribution. It was checked that it is the stress distribution almost parallel to the direction of an axis from this calculation result in the domain between the semicircle-like projection parts of an up-and-down side which apply axial force.

\section{3・3 有限要素法を用いた解析結果}

前節で設定した解析モデルと境界条件を用いて有限要素法を用いた解析を行った結果のうち，応力分布のべク トル線図を図 6 に示した。この図に示した計算結果によると，荷重のかかる上下面の半円状突起部の間の領域に おいて，軸方向にほぼ平行な最大主応力分布になっていることがわかった。 このとき図 5 において，光ファイバ 一FBG 素子の設置を想定してボルト軸から 20 度だけ傾いた座標系 $\mathrm{S}$ 軸上の応力分布を図 7 に示した. それぞれ, 困 7a)は軸力荷重, 図 7b)はモーメント荷重によって生じる応力分布である. 解析時に軸力荷重の場合 $1 \mathrm{~N}$, モ一 メント荷重の場合は $1 \mathrm{Nm}$ のように単位荷重を印加していることから，同図の縦軸は $\mathrm{S}$ 軸上応力の荷重あるいは トルク感度とみなすことができる。

この計算結果によると，まず軸力については，光ファイバー軸上の位置 $s=-2.0 \sim 2.0 \mathrm{~mm}$ の領域において，比 較的線形な変化傾向を示す応力分布を示しており，このことは光ファイバーFBG 素子からの反射光スペクトル形 状のひずみを小さくできるため好都合である.

次に，実際にグレーティング長 $4.0 \mathrm{~mm}$ の光ファイバーFBG 素子を $s=-2.0 \sim 2.0 \mathrm{~mm}$ の領域に設置した場合を

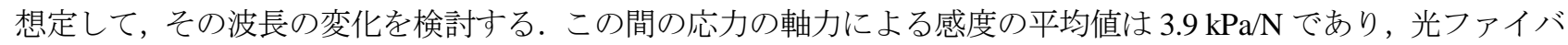
一の縦弾性係数が石英ガラスと同等の $72 \mathrm{GPa}$ であることを考慮すると，光ファイバーFBG 素子のひずみのボル 卜軸力感度は $0.056 \times 10^{-6} \mathrm{~N}^{-1}$ である. さらに式(3)を用いて，このひずみによる光ファイバーFBG 素子の反射波長 への軸力感度に換算すると, $0.085 \mathrm{pm} / \mathrm{N}$ の感度が得られた. 一方, 図 7b)に示した応力のトルクによる感度は, 同じ位置 $s=-2.0 \sim 2.0 \mathrm{~mm}$ の領域において, $0.097 \mathrm{kPa} / \mathrm{Nm}$ であり, 光ファイバーFBG 素子の波長変化 $\Delta \lambda に$ 換算 すると, $6.3 \times 10^{-5} \mathrm{pm} / \mathrm{Nm}$ となった。

今回計測対象として想定した M10 ボルトにおける標準軸力は $12250 \mathrm{~N}$ であり，このとき上述のセンサの波長変 化は約 $1.0 \times 10^{3} \mathrm{pm}$ となる. このことと，一般に光ファイバーFBG センサの計測に用いられる計測器インテロゲ 一タの波長計測精度が $1 \mathrm{pm}$ 以下であることを考慮すると約 $1 / 1000$ の分解能が得られる. このことから，ここで 設計したワッシャ型軸力センサは十分な軸力感度を有することが期待される. また一方，このときのトルクにつ いては，標準締付トルク $24.5 \mathrm{Nm}$ における波長変化が $1.5 \times 10^{-3} \mathrm{pm}$ であり，光波長の変動は十分小さく，この影 響は実用上問題にはならないものと考えられる. 


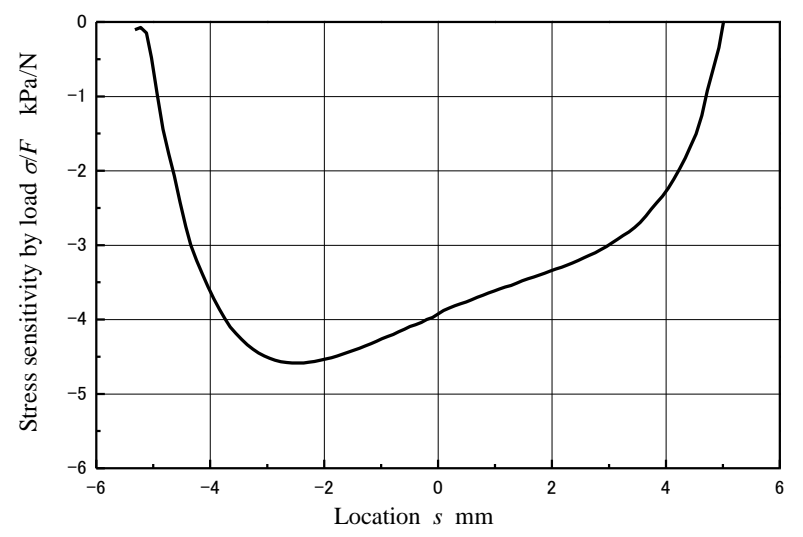

a) Axial Force.

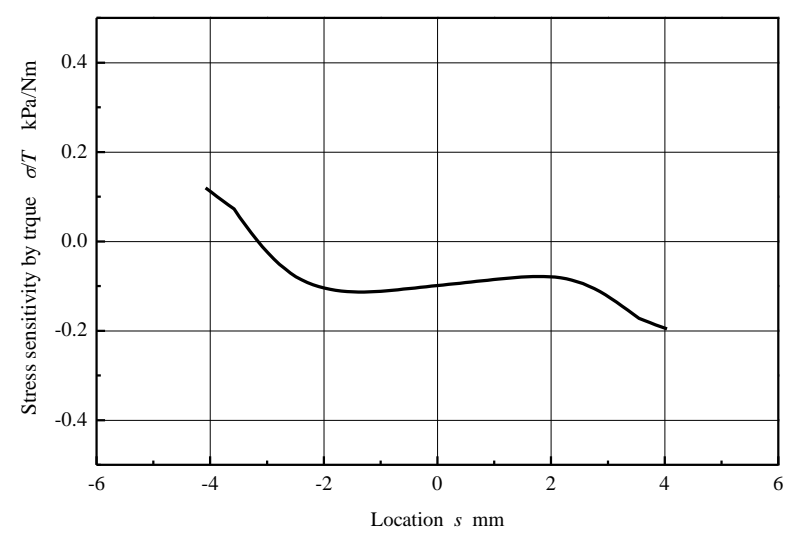

b) Torque

Fig.7 Analytical result of FEM analysis: This plot shows the stress distribution on S-axis generated by axial force or torque. The stress distribution which generated with axial force is linear distribution in general from domain $\mathrm{s}=-2 \mathrm{~mm}$ to $+2 \mathrm{~mm}$. On the other hand, the stress distribution which generated by torque is a sufficiently small value.

\section{4.＼cjkstart軸カセンサ特性実験}

\section{$4 \cdot 1$ 試作した軸カセンサと軸力特性実験方法}

特性試験のために試作したボルト軸カセンサを図 8 に示した。 センサは SUS304 ステンレス製で，解析と同じ

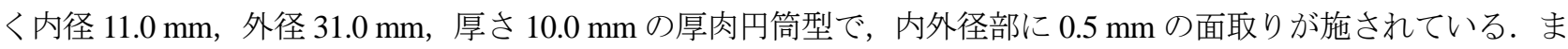
た，光ファイバー取出し部には光ファイバーの折損を防止するために保護金具部を設けている．また，ここで使 用した光ファイバーFBG 素子は反射波長 $\lambda_{B}$ が $1550 \mathrm{~nm}$ で, グレーティング長は $4.0 \mathrm{~mm}$ である. 光ファイバーFBG 素子は，軸力センサの内径側に軸と 20 度の角度で設けた幅 $0.3 \mathrm{~mm}$ のスリット状溝内に，抵抗線ひずみゲージ用 のエポキシ系接着剤（(株)共和電業，EP-34B）で接着して固定した.

軸力によるセンサ特性試験では，図 9 に示したように，軸力センサの荷重を受ける円周状突起部に均一に荷重 が掛かるように球状治具を用いた．荷重の印加には万能材料試験機（UH-F300,(株)島津製作所）を用い，ステッ プ状に荷重を調整して印加した。

またこのとき，光ファイバーFBG 素子から得られる光スペクトルの計測には，図 10 に示した光計測回路を 用いた。 
光回路の構成には，広い波長帯域の光を得られる ASE 光源（ASE-FL7002，FiberLabs Inc.)，波長分布を計測す る光スペクトラムアナライザ (AQ6331, 安藤電機(株)) と光の進行方向を制御する光サーキュレータ (6015-3-FC, ThorLabs Inc.）を用いた. まず ASE 光源を発した光は光サーキュレータを通ってボルト軸力センサに入射する. 試作した軸力センサに埋め込まれた光ファイバーFBG 素子によって特定の波長のスペクトルのみ反射され, 光フ アイバー内を逆方向に戻ってくる. このとき, 光サーキュレータに戻った反射光は光スペクトラムアナライザに 導かれ，これに入射する. この反射光は光スペクトラムアナライザを用いて解析され，スペクトル分布を観察・ 計測し, データ解析に用いた。

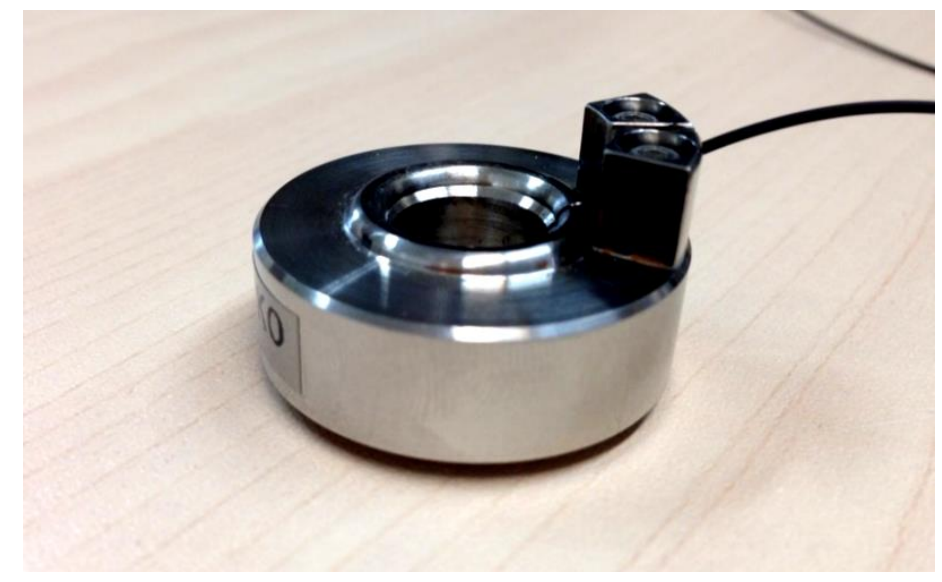

Fig.8 Axial force sensor using optical fiber FBG device for experiment.

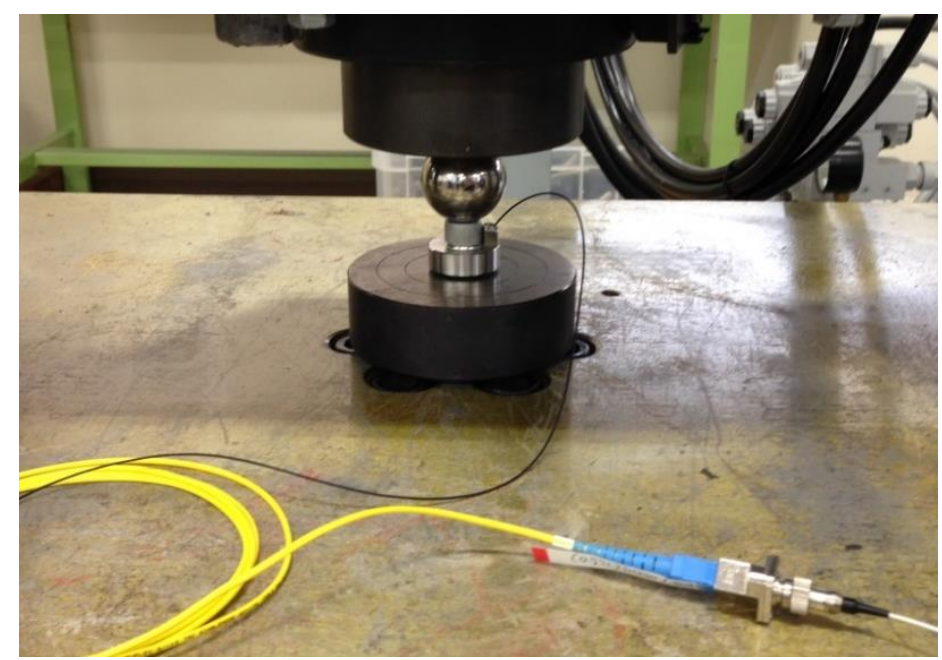

Fig.9 Experimental arrangement for measurement of the properties on the axial force sensor.

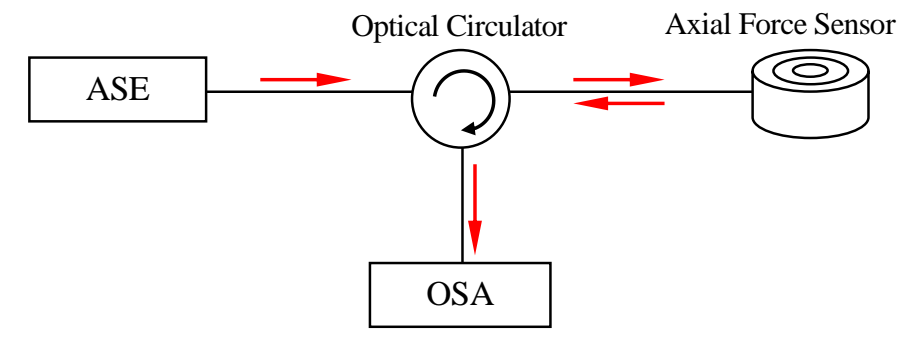

ASE : Amplified Spontaneous Emission Light Source

OSA : Optical Spectrum Analyzer

Fig.10 Optical circuit of experiment system to measure the FBG spectrum. 


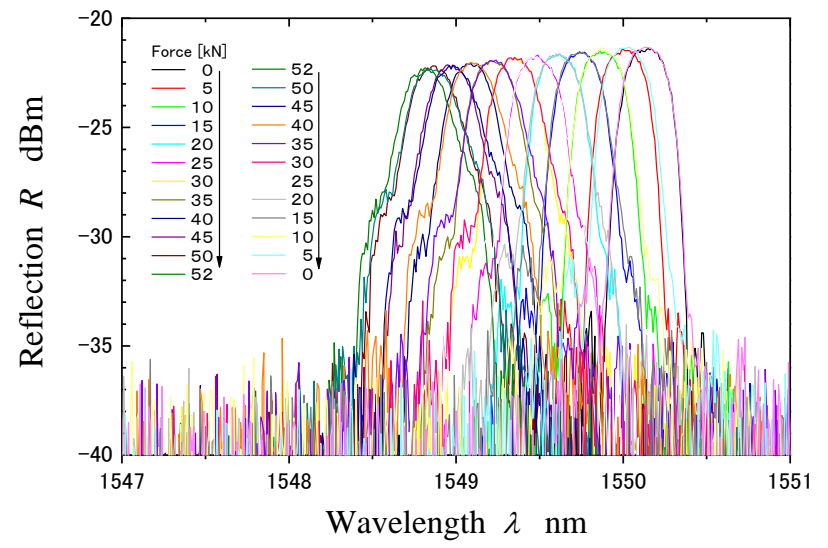

Fig.11 Reflection spectrum from axial force sensor and change of spectrum in each step load.

Axial force increased from non-load to $50 \mathrm{kN}$ at $5 \mathrm{kN}$ step, and decreased after that. Change of the spectrum is plotted for each of this step. The spectrum changed to short wavelength with the increase in axial force, and returned with reduction.

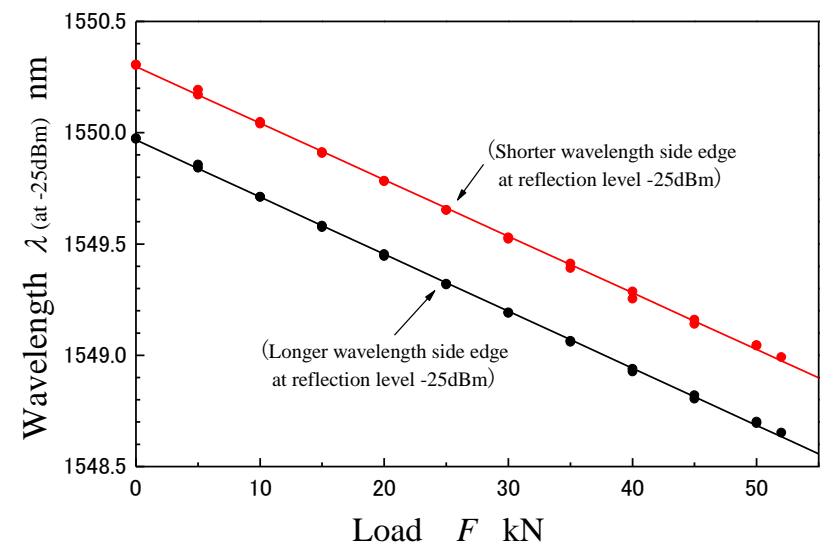

Fig.12 Wavelength shift properties of axial force sensor depending on axial load.

Change of the light wavelength of the edge in light intensity $-25 \mathrm{~dB}$ of the spectrum by change of axial force is plotted. The light wavelength changed in proportion to axial force.

\section{$4 \cdot 2$ センサ特性実験の結果}

光計測回路を含む実験装置を用いて，試作したワッシャ型ボルト軸カセンサの特性計測実験を行った.

軸力センサに埋め込まれた FBG 素子の反射スペクトルを, 図 11 に示した. FBG 素子の反射スペクトルは, Bragg 波長を中心に約 $0.5 \mathrm{~nm}$ の带域幅を有し概社半波正弦波状の分布を示寸. 特性実験では無荷重から荷重を $5 \mathrm{kN}$ ス テップで載荷してゆき， $50 \mathrm{kN}$ になったのち最大 $52 \mathrm{kN}$ を印加して折り返し，逆にステップ除荷していった。 こ のときの軸力センサの反射スペクトルの推移も同図に示した.このとき荷重載荷とともに軸力センサが圧縮され， 反射スペクトルのピーク波長が $1550.1 \mathrm{~nm}$ から短波長側に推移し, $1548.8 \mathrm{~nm}$ まで移動する. 逆に除荷してゆくと 長波長側に推移し，無負荷となったとき初期の反射スペクトルに戻った。この間，反射スペクトルはほぼ一定の 半波正弦波状で推移しており, 軸力センサ内部 S 軸上の応力分布形状がほぼ安定していることを確認できた. 
次に，このときの軸力荷重印加による反射波長の推移を，図 12 に示した. これは図 11 の反射スペクトルにお いて，スペクトル両サイドで反射光量が- $25 \mathrm{dBm}$ となる波長端をプロットしたものである. 図のように，軸力荷 重と反射波長の変化には比例関係がみられる. 光ファイバーFBG 素子の反射波長への軸力感度を $k$ としたとき, この関係は次式,

$$
\Delta \lambda=k \cdot F
$$

として表されるが，実験結果から得られた軸力感度 $k$ は， $k=0.0257 \mathrm{pm} / \mathrm{N}$ であった。この值は 3.2 節において有 限要素法を用いた解析結果から推定した值 $0.085 \mathrm{pm} / \mathrm{N}$ と比較すると 0.30 倍に低下している.

この原因は光ファイバーFBG 素子のワッシャ型センサ内への接着原因があるものと考えられる．まず，通常の 抵抗線ひずみゲージの抵抗䈃の断面積が約 $2500 \mu \mathrm{m}^{2}$ であるのに比べて, 光ファイバーFBG 素子の場合, 石英ガ ラス部の直径が $125 \mu \mathrm{m}$ で断面積が $12270 \mu \mathrm{m}^{2}$ であり，抵抗線ひずみゲージの約 5 倍の断面積になりこれに伴っ て剛性が高くなっている. 一方, 直径 $0.125 \mathrm{~mm}$ の円柱状の光ファイバーを幅 $0.3 \mathrm{~mm}$ のスリットの内部に接着し ているため，センサ金属面に面状に接着させることが困難であり，金属面が光ファイバーと線接触した周りに接 着剂を充填した構造になる. このため接着層の平均害効厚さも光ファイバー直径の数分の一程度が見込まれ，セ ンサ側のひずみを光ファイバーに接着層の弾性を通じて伝えることになる. 更に光ファイバーFBG 素子のセンサ 内一の固定には抵抗線ひずみゲージ用のエポキシ系接着剤を使用したが，この弾性係数は通常，金属やガラスな どと比べてかなり小さな值である，このことから，感度低下の原因は，光ファイバーFBG 素子の直径による高剛 性と接着剤の弾性によるひずみ緩和が原因と考えられる.このことは通常の構造物表面のひずみ計測に接着剤で 貼り付けた光ファイバーFBG 素子を用いたときに必ず生じる問題である. この感度低下は今後, 例えば細径光フ アイバー(水谷他，2001)などを用いることなどによって軽減されるものと考えられる.

\section{5. 結 語}

ひずみ計測に光ファイバーFBG 素子を用いたワッシャ型ボルト軸力センサの研究を行った．本センサは，ひず み検出と信号伝送に光ファイバーを用いているため, 電磁ノイズへの而性があり, しかも長距離信号伝送が可能 といらメリットがある.

センサの構造では，ボルト座面の圧力分布の不安定さによるセンサ出力特性のばらつきを防止するため，ボル 卜座面とセンサとの接触部に円周状の突起部を設けてボルト軸力の作用半径をこの突起部に固定することによっ て，ボルト軸力に比例して安定した応力分布と信号出力が得られるように工夫した.

センサの解析では, 光ファイバーFBG 素子に作用する軸方向応力分布の特性を, 有限要素法を用いた解析によ って求めた．その結果，ボル卜軸力に対して十分大きい信号が得られることがわかった．また，卜ルクの影響に 関しては実用上無視できる感度であることがわかった。

センサ特性実験では，まず解析計算結果等に基づいて M10 ボルト用ワッシャ型ボルト軸力センサを試作した. このセンサの特性計測実験の結果，このボルト軸力センサでは，解析計算から推定した值の約 0.3 倍であったが 軸力センサとして必要な軸力感度が得られるとともに, 軸力に比例して光ファイバーFBG 素子の反射波長がほぼ 線形にシフトする良好な特性が得られた。

今後さらに, 軸力センサとして実用化のために, 信頼性や計測精度の向上や検証などを行ってゆく予定である.

最後に, 本研究を遂行する上で多大なご支援をいただいた伸興電線株式会社の尾崎雅宣工場長と志賀俊也部長 をはじめとする社員各位に感謝の意を表します，さらに，特性実験の実施には，香川高等専門学校技術教育支援 センターの大賀祐介氏と丸笹憲志氏にご協力いただきました。 ここに感謝の意を表します.

\section{文献}


賀勢晋司, ねじ締結における座面圧について, 精密工学会誌 Vol. 51, No.5 (1985), pp.997-999.

水谷忠均,岡部洋三,武田展雄, 細径 FBG センサによるクラック検出手法のCFRP議事等方性積層板への応用, 日本

機械学会第 9 回機械材料・材料加工技術講演会論文集(2001),p.114.

Rybczynski, W., ねじとねじ回しこの千年で最高の発明をめぐる物語, 早川書房 (2003).

山本晃,賀勢晋司, 軸直角振動によるねじのゆる久に関する研究, 精密機械 Vol.43, No.4 (1977), pp.470-475.

\section{References}

Kasei, S., Bearing Surface Pressure on Bolted Joint, Journal of Japan Society for Precision Engineering, Vol. 51, No. 5 (1985), pp. $997-999$ (in Japanese).

Mizutani, T., Okabe, Y. and Takeda, N., Application of Crack Detection by Small-Diameter FBG Sensors to CFRP Quasi-Isotropic Laminates, Proceeding of the 9th Materials and Processing Conference(M\&P2001), p.114 (in Japanese).

Rybczynski, W., ONE GOOD TURN: A Natural History of the Screwdriver and the Screw, HAYAKAWA Shobo (2003) (in Japanese).

Yamamoto, A. and Kasei, S., Investigations on the Self-loosening of Threaded Fasteners under Transverse Vibration-A Solution for Self-loosening Mechanism- , Journal of Japan Society for Precision Engineering, Vol.43, No.4(1977), pp.470-475 (in Japanese). 